\title{
ESTIMATION OF LEAD AND CADMIUM LEVELS IN FLESH OF SOME IMPORTED SALTED CANNED FISH
}

\author{
NAHED M. ABDELAZIZ* and Z.M. ZAKY** \\ * Department of Food Hygiene, Fac. of Vet. Med., Sohag Univerisity, Sohag, Egypt. \\ ** Department of Forensic Medicine and Toxicology Fac. of Vet. Med., Assiut Univerisity, Assiut, Egypt.
}

Email: nahedvet2012@yahoo.com $\quad$ Assiut University web-site: $\underline{\text { www.aun.edu.eg }}$

\section{ABSTRACT}

Received at: 30/3/2015

Accepted: 30/4/2015
Fish accumulates substantial amounts of metals in their tissues especially muscles and thus, consider one of major dietary sources of these metals for humans. The objective of the present study is to determine the concentration of lead and cadmium levels in flesh of some imported salted canned fish (Sardine, Salmon and Anchovies) by Atomic Absorption Spectrophotometer with Graphite furnace. Fourty five imported canned salted fish were collected from different supermarkets in Sohag city produce during 2014. Samples were divided into three groups (15 for each) according to the geographic areas of production (G1 from Thailand, G2 from Morocco and G3 from Spain). Each group was subdivided into three (5 each) subgroup (Sardine, Salmon and Anchovies). Our results revealed that lead mean \pm SE (wet weight) levels were 2.495 $\pm 0.013,2.320 \pm 0.010$, $0.271 \pm 0.047 \mathrm{ppm}$ in sardine, $0.298 \pm 0.158,0.452 \pm 0.127 \mathrm{ppm}$ and $0.275 \pm 0.132$ in salmon and 6.939 $\pm 2.370,2.060 \pm 0.061$ and $2.691 \pm 0.473 \mathrm{ppm}$ in anchovies flesh in G1, G2 and G3 respectively. For cadmium mean levels \pm SE (wet weight) were $0.063 \pm 0.011,0.098 \pm 0.025$ and $0.066 \pm 0.021$ in sardine flesh, $0.037 \pm 0.009$, $0.053 \pm 0.010$ and $0.061 \pm 0.020$ in salmon flesh and $1.007 \pm 0.093,0.464 \pm 0.055$ and $1.908 \pm 0.540$ in Anchovies ppm, in G1, G2 and G3 respectively. According to data presented in this study, it can be concluded that lead levels in flesh of salted canned fish collected from Sohag city were above the Egyptian Organization for Standardization and Quality Control EOSQC. (1993) recommended limit in sardine and anchovies and below this limit in salmon. Cadmium values were below the established values in all samples except G2 of anchovies. It recommended that more research and assessments of seafood quality is needed to provide more data and help safeguard the health of consumers.

Key word: Lead and cadmium, Flesh, Imported salted canned fish.

\section{INTRODUCTION}

Fish is widely consumed in many parts of the world by humans because it has high protein content, low saturated fat and also contains omega fatty acids known to support good health (US EPA, 2004). It have been found to be good indicators of heavy metal contamination in aquatic systems (Burger et al., 2002).

Canned fishes in particular are well eaten in the developed world it is convenient and affordable for most working families (NOAA, 2002).
Fish may be contaminated by toxic elements during fish growth, transportation, and storage. Contamination may also occur during production, handling and canning process. Information on the metal content in canned fish is important to ensure that the fish consumed is safe for human consumption. The estimated weekly intakes of these metals by adults consuming different species of canned fish are also evaluated for possible human health risks (Ikem and Egiebor (2005).

Heavy metals are potential environmental contaminants with the capability of causing human health problems if present to excess in the food. They 
are given special attention throughout the world due to their toxic effects even at very low concentrations (Das, 1990). Several cases of human disease, disorders, malfunction and malformation of organs due to metal toxicity have been reported (Jarup, 2003).

Lead is a heavy metal that accumulates in the body and affects different systems and organs such as central and peripheral neural system, gastrointestinal tract, muscles, kidneys and hematopoietic system Ciobanu et al. (2012). Short-term exposure to high levels of lead can cause brain damage, paralysis (lead palsy), anemia and gastrointestinal symptoms. Longer-term exposure can cause damage to the kidneys, reproductive and immune systems in addition to effects on the nervous system (Rose et al., 2001).

Cadmium and lead are among the most abundant heavy metals and are particularly toxic. The excessive content of these metals in food is associated with etiology of a number of diseases (WHO, 1992, 1995).

International Agency for Research on Cancer (IARC) classified cadmium and lead as human carcinogen (IARC, 1993; Steenland and Boffetta, 2000).

Cadmium exposure induces bone damage, osteoporosis, and renal tubular dysfunction that leads to renal failure in long term (Ciobanu et al., 2012) and Engström et al. (2012), It is also associated with several cancers (Satarug, 2012) and Sawada et al. (2012).

The present study was carried out to determine the current levels of total lead and cadmium in the muscle tissue of canned salted fish samples, imported from different countries and compare with the guidelines set down by FAO/WHO (1992) and EOSQC (1993).

\section{MATERIALS and METHODS}

\section{Sampling}

A total of forty five imported salted canned fish (15 each of Sardine Salmon, and Anchovies) were collected from different markets in Sohag city, Egypt that divided according geographical areas of production during 2014 (G1, G2, G3).

Lead and cadmium were determined by using ZEEnit 700P Atomic Absorption Spectrophotometer with Graphite furnace (AASG) (Atomic Absorption Spectrophotometer model AnalytikjenaAG, USA) in the Central Laboratory of the Faculty of Veterinary Medicine, Assiut University, Egypt. $0.5 \mathrm{~g}$ was weighed into a set of digestion tubes. $10 \mathrm{ml}$ of nitric acid was mixed into the sample vessels. Mixture of content of the digestion tubes were then digested by Microwave at a temperature of $60^{\circ} \mathrm{C}$ for $30 \mathrm{~min}$. The digestion was cooling to room temperature and diluted with ultra-pure water to make a volume of 25 $\mathrm{ml}$, put in clean glass vials and kept till analysis.

The combined stock standard ( $\mathrm{Pb}$ and $\mathrm{Cd}$ (1000 ppm each) was prepared from reference standards and stored in the refrigerator until use. The method of calibration curve was used for calibration and quantification of the AAS to its effective position. The working standards were first determined to create the standard curve; this was followed by the measurement of the unknown analyses. The atomic absorption spectrophotometer was adjusted to specific wavelength corresponding to each of the metals to be measured.

\section{Statistical Analysis}

Statistical analysis was performed using SPSS 13.0 for Windows. Analysis of Variance (ANOVA) was used and statistical significance was set at $\mathrm{P}<0.05$. Duncan Multiple Range Test was used to separate differences in treatment means.

\section{RESULTS}

Table 1: Mean lead levels $\pm \mathrm{SE}$ in muscle of Sardine, Salmon, and Anchovies from Thailand (G1), Morocco (G2) and Spain (G3) and number of samples tested in each group (No).

\begin{tabular}{lccccccccc}
\hline \multirow{2}{*}{ Groups } & \multicolumn{1}{c}{ Sardine } & \multicolumn{9}{c}{ Salmon } & \multicolumn{2}{c}{ Anchovies } \\
\cline { 2 - 9 } & Mean & SE & NO. & Mean & SE & NO. & Mean & SE & NO. \\
\hline G1 & 2.495 & 0.013 & 5 & 0.298 & 0.158 & 5 & 6.939 & 2.370 & 5 \\
\hline G2 & 2.320 & 0.010 & 5 & 0.452 & 0.127 & 5 & 2.060 & 0.061 & 5 \\
\hline G3 & 0.271 & 0.047 & 5 & 0.275 & 0.132 & 5 & 2.691 & 0.473 & 5 \\
\hline
\end{tabular}


Figure (1) lead concentration (ppm) in tested (sardine, salmon and anchovies) samples
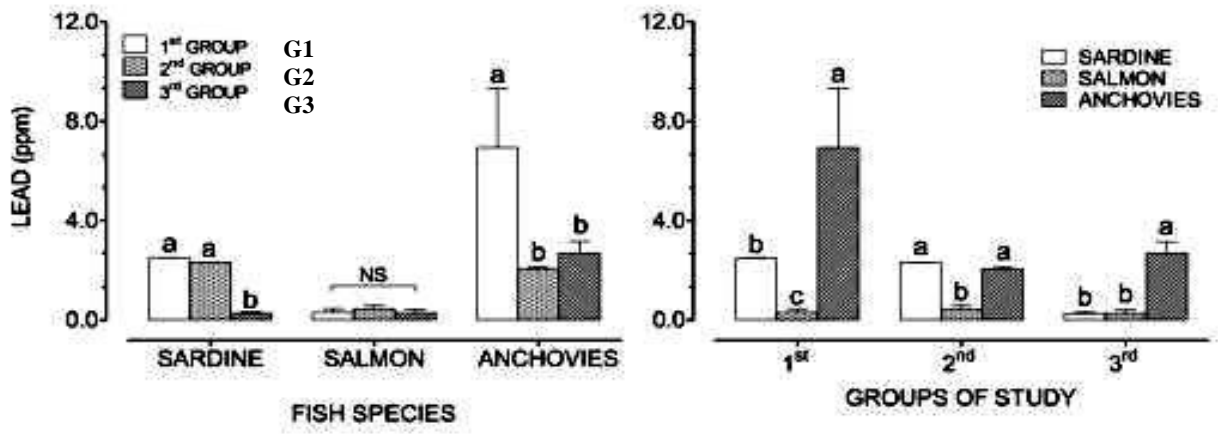

Letters on bars $(\mathrm{a}, \mathrm{b}, \mathrm{c})$ denote the significant differences among groups $(\mathrm{P}<0.05)$.

Table 2: Mean values \pm SE of cadmium levels in muscle of Sardine

Salmon, and Anchovies from Thailand (G1), Morocco (G2), and Spain (G3) and number samples tested in each group (No).

\begin{tabular}{llllllllll}
\hline & \multicolumn{2}{c}{ Sardine } & \multicolumn{3}{c}{ Salmon } & \multicolumn{5}{c}{ Anchovies } \\
\cline { 2 - 10 } & Mean & SE & NO. & Mean & SE & NO. & Mean & SE & NO. \\
\hline G1 & 0.063 & 0.011 & 5 & 0.037 & 0.009 & 5 & 1.007 & 0.093 & 5 \\
\hline G2 & 0.098 & 0.025 & 5 & 0.053 & 0.010 & 5 & 0.464 & 0.055 & 5 \\
\hline G3 & 0.066 & 0.021 & 5 & 0.061 & 0.020 & 5 & 1.908 & 0.540 & 5 \\
\hline
\end{tabular}

Figure (2) Cadmium concentrations (ppm) in fish species; Sardine, Salmon and Anchovies samples.
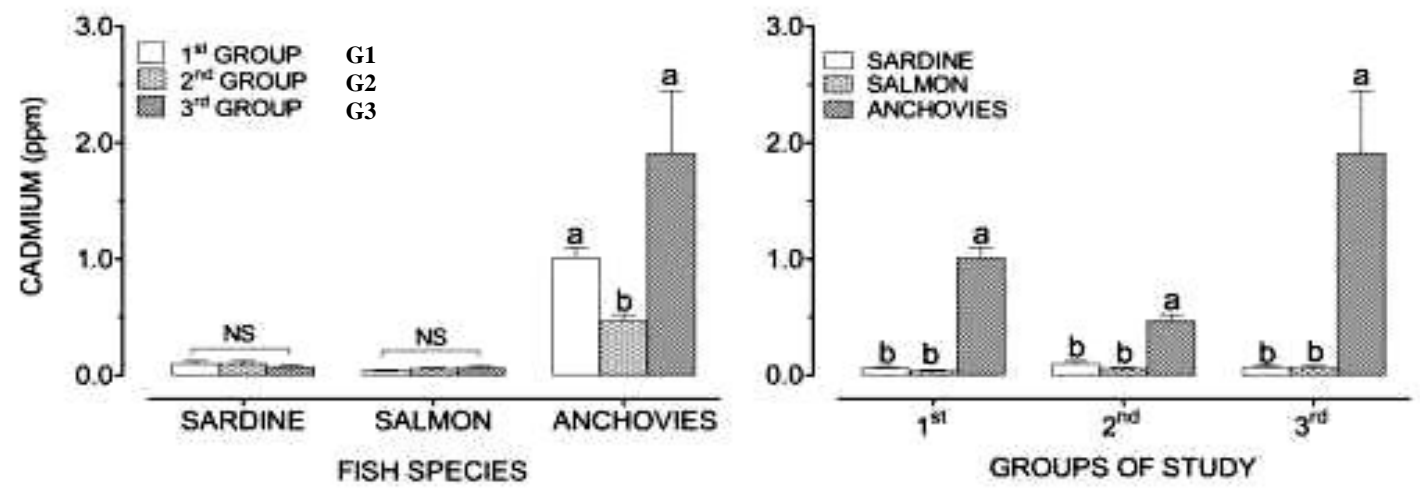

NS means non-significant differences. 


\section{DISCUSSION}

The average values of lead in G1, G2 and G3 in sardine showed were $2.495 \pm 0.013,2.320 \pm 0.010$, $0.271 \pm 0.047 \mathrm{ppm}$ respectively which higher than $(0.1$ ppm) that recommended by EOSQC (1993) while G3 had lower lead level than the limit of $(0.5 \mathrm{ppm})$ that reported by FAO/WHO (1992). These result are similar to result recorded by Rafael (1975), 0.13-2.15 ppm in Spanish sardine, Olga Marta et al. (1991) recorded the levels of lead as 0.29-0.72 ppm in Costa Rica, also as Ashraf et al. (2006) $0.84 \pm 0.46$ ppm in Saudi Arabia and Tarley et al. (2001), 0.77-2.15 ppm in Brazil.

Lead levels in salmon were $0.298 \pm 0.158$, $0.452 \pm 0.127$ and $0.275 \pm 0.132 \mathrm{ppm}$ in G1, G2, and G3 respectively. These levels are higher than the permissible limit recorded by EOSQC (1993) and lower than that recorded by FAO/WHO. (1992). Ashraf et al. (2006) recorded a same level value of lead in salmon $(0.31 \pm 0.11) \mathrm{ppm}$ in Saudi Arabia.

In anchovies the lead levels were 6.939 \pm 2.370 , $2.060 \pm 0.061,2.691 \pm 0.473 \mathrm{ppm}$ in G1, G2, and G3, respectively. These values are higher than the limits recommended by EOSQC (1993) and FAO/WHO (1992). Similar result were obtained with Türkmen et al. (2008) ( $0.87 \pm 0.40 \mathrm{ppm}$ in samples collected from Black sea and Tüzen (2009) $0.30 \pm 0.02 \mathrm{ppm}$ in Turkey but the result recorded by Gilmartin and Revelante (1974) from Adriatic sea were lower than our result $<0.01$.

The mean values of cadmium in sardine were $0.063 \pm 0.011,0.098 \pm 0.025$ and $0.066 \pm 0.021 \mathrm{ppm}$, while in salmon were $0.037 \pm 0.009,0.053 \pm 0.010$ and $0.061 \pm 0.020 \mathrm{ppm}$, in anchovies were $1.007 \pm 0.093$, $0.464 \pm 0.055$ and $1.908 \pm 0.540 \mathrm{ppm}$, in G1, G2 and G3, respectively. In all samples the cadmium levels are lower than $(0.1 \mathrm{ppm})$ that recommended by EOSQC (1993) and also lower than (0.5 ppm) that recommended by FAO/WHO (1992) except the third group in anchovies was higher than the permissible limits.

A similar results of cadmium levels in sardine were reported by Suppin et al. (2005) in Austria was (0.012 ppm), Olga Marta et al. (1991) in Costa Rica (0.06$0.16 \mathrm{ppm}$ ), Ashraf et al. (2006) in Saudi Arabia (0.18 $\pm 0.19 \mathrm{ppm}$ ) and Gilmartin and Revelante (1974) from Black sea recorded lower levels than our result $<0.01$.

\section{REFERENCE}

Ashraf, W.; Seddigi, Z.; Abulkibash, A. and Khalid, M. (2006): Levels of selected metals in canned fish consumed in Kingdom of Saudia Arabia, Envirpnmental Monitoring and Assessment $\mathrm{V}(117)$ issue 1-3, pp 271-279.
Burger, J.; Gaines, K.F.; Shane Boring, C.; Stephens, W.L.; Snodgrass, J.; Dixon, C.; McMahon, M.; Shukla, S.; Shukla, T. and Gochfeld, M. (2002): Metal levels in fish from the Savannah river: potential hazards to fish and other receptors. Environmental Research 89, 85-97.

Ciobanu, C.; Slencu B.G. and Cuciureanu, R. (2012): Estimation of dietary intake of cadmium and lead through food consumption. Rev. Med. Chir. Soc. Med. Nat. Iasi., 116(2): 617-623.

Das, A. (1990): Metal ion induced toxicity and detoxification by chelation therapy. In: 1 st(ed) A text book on medical aspects of bioinorganic chemistry, CBS, Delhi, p. 17-58.

Engström, A.; Michaëlsson, K.; Vahter, M.; Julin, B.; Wolk, A. and Akesson, A. (2012): Associations between dietary cadmium exposure and bone mineral density and risk of osteoporosis and fractures among women. Bone, 50: 1372-1378.

EOSQC "Egyptian Organization for Standardization and Quality Control" (1993): Maximum residue limits for heavy metals in food, Ministry of Industry No. 2360: 5, Cairo, Egypt.

FAO/WHO (1992): Codex Alimentarius Commission, standard program codex committee on food additives and contaminants 24th Session, Hague, 23-28 March.

Gilmartin, M. and Revelante, N. (1974): The concentration of mercury, copper, nicklemsilver, cadmium and lead in the northern Adriatic anchovy engraulis encrasicholus, and sardine, sardine pilchardus J. Fishery Bulletin vol. 73. no1 pp193: 201.

IARC (1993): Cadmium and cadmium compounds. In: Beryllium, cadmium, mercury and exposure in the glass manufacturing industry. IARC Monographs on the evaluation of carcinogenic risks to humans, Vol. 58., 119-23, International Agency for Research on Cancer, Lyon.

Ikem, A. and Egiebor, N. (2005): Assessment of trace elements in canned fishes (mackerel, tuna, salamon, sardines and herrings) marketed in Georgia and Alabama (United States of America), J. of Food Composition and Analysis 771-787.

Jarup, L. (2003): Hazards of heavy metal contamination. British Medical Bulletin 68: 167-182.

NOAA "National Oceanic and Atmospheric Administration" (2002): Shrimp overtakes canned tuna as top US seafood- overall seafood consumption decreases in 2001. NOAA 2002-113, available at: http://www. publicaffairs.noaa.gov/releases2002/aug02/ noaa02113.html.

Olga Marta.; Jorge Arturo, C. and Maria Elena, A. (1991): Lead, cadmium and tin content in fresh 
and canned Costa Riccan sardines and tuna, Ingenieriy Ciencia Quimica 13 (1), 20-24.

Rafael, E. (1975): Study of the cadmium and lead contents Spanish canned fish and mollusk, Informs Tecinos del Instituto de Investigations Pesqueras (Barcelona), pp.14-29.

Rose, M.; Knaggs, M.; Owen, L. and Baxter, M. (2001): A review of the analytical methods for lead, cadmium, mercury, arsenic and tin determination used in proficiency testing. Journal of Analytical Atomic Spectrometry, 16, 1101-1106.

Satarug, S. (2012): Long-term exposure to cadmium in food and cigarette smoke, liver effects and hepatocellular carcinoma. Curr Drug Metab 2012, 13(3): 257-271.

Sawada, N., Iwasaki, M., Inoue, M., Takachi, R., Sasazuki, S., Yamaji, T., Shimazu, T., Endo, Y. and Tsugane, S. (2012): Long-term dietary cadmium intake and cancer incidence. Epidemiology, 23(3): 368-376.

Steenland, K. and Boffetta, P. (2000): Lead and cancer in humans. Med. 38: 295-299.

Suppin, D.; Zahlbruckner, R.; Krapfenbauer-Cermak, Hassan, CH. and Smulders, F. (2005): Mercury, lead and cadmium content of fresh and canned fish collected from Austrian retail operations Ernahrung/Nutrition/, vol 29/NR. 112.

Tarely, T.R.; Coltro, T.K.; Matsushita, M. and Souza, N. (2001): Characteristic levels of some heavy metals from Brazilian canned sardines (Sardinella brasiliensis) J. of Food Composition And Analysis 14, pp 611-617.

Türkmen, A.; Tepe, Y. and Türkmen, M. (2008): Metal levels in tissues of the European anchovy, Engraulis encrasicolus L., 1758, and picarel, Spicara smaris L., 1758, from Black, Marmara and Aegean Seas. Bulletin of enviromental contamination and toxicology, 80: 521-5. doi: 10.1007/s00128-008-9429-2.

Tüzen, M. (2009): Toxic and essential trace elemental contents in fish species from the Black Sea, Turkey. Food and Chemical Toxicology, 47:1785-1790. doi: 10.1016/j.fct.2009.04.029.

US EPA "United States Environmental Protection Agency" (2004): What you need to know about mercury in fish and shellfish. EPA-823-F- 04009, 2pp, availableat: http://www.epa.gov/ waterscience/fish/MethylmercuryBrochure.pdf.

WHO (1992): Cadmium. Environmental Health Criteria, Vol. 134, Geneva.

WHO (1995): Lead. Environmental Health Criteria, Vol. 165, Geneva.

\section{تقدير مستويات الرصاص والكادميوم فى بعض الأسماك المعلبة المملحة المستوردة ناهل محمود عبل العزيز ، زكريا مختار زكى}

Email: nahedvet2012@yahoo.com_Assiut University web-site: www.aun.edu.eg

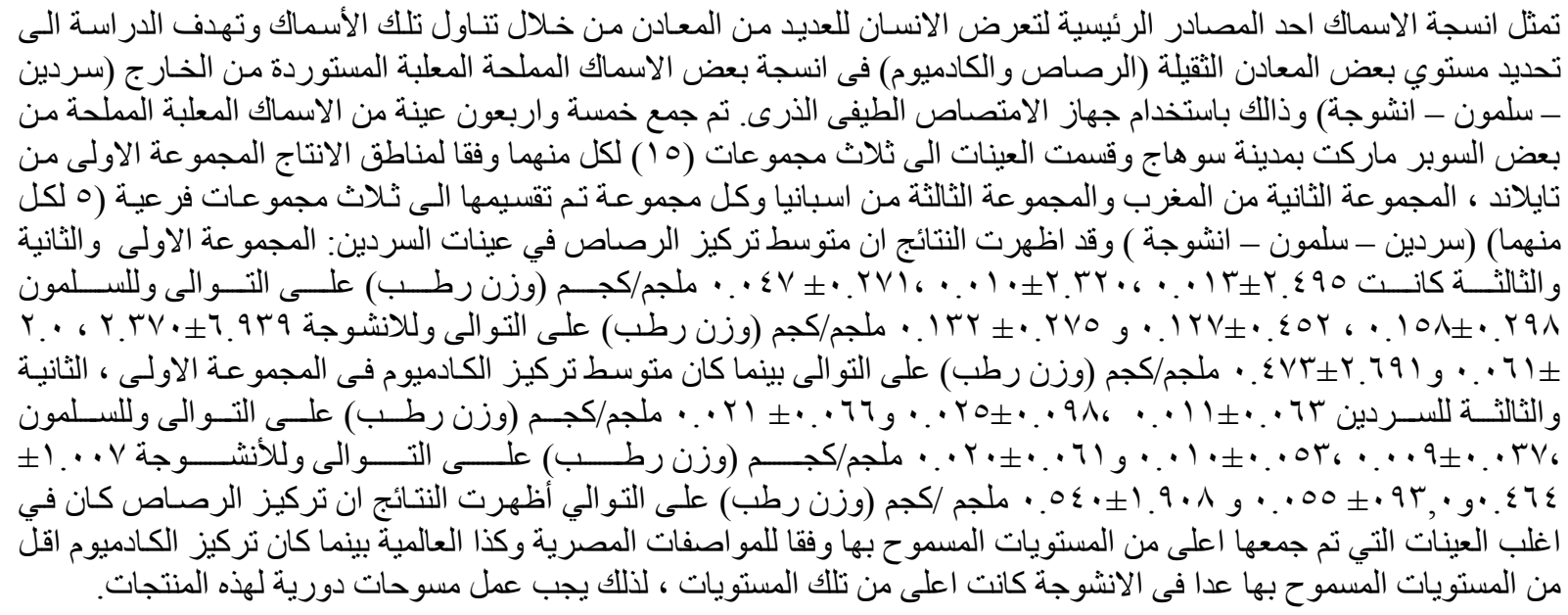

